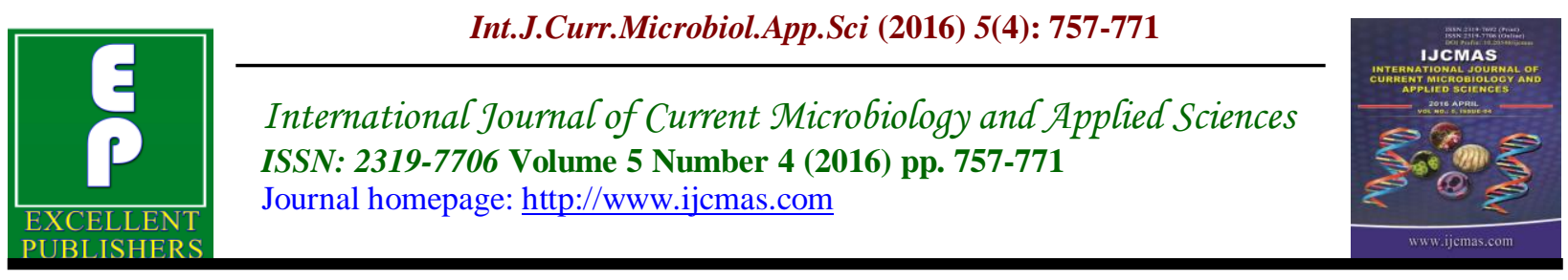

Original Research Article

http://dx.doi.org/10.20546/ijcmas.2016.504.087

\title{
Impacts of Printing Presses Emissions upon Occupationally Exposed Workers Health
}

\author{
Zainab N. Abdulateef* and Adel H. Talib \\ College of science for Women, Baghdad University, Baghdad, Iraq \\ *Corresponding author
}

\begin{abstract}
A B S T R A C T
Keywords

Printing Presses

Emissions,

Expiratory Flow,

Forced Expiratory

Flow,

hemoglobin,

hematocrit

\section{Article Info}

Accepted:

22 March 2016

Available Online:

10 April 2016

Printing presses may cause different pollutants which may have various environmental and health effects upon those occupationally exposed workers. The results obviously showed highest values of lead and zinc blood content in occupationally exposed sample respectively in comparison with the other groups. In contrast, the study recorded highest values of blood copper concentration in environmental exposure samples as a compared with the other groups. Blood parameters indicated to significant decreases of white blood cells concentrations in workers blood which is lower than the control samples. The study found that the hemoglobin, hematocrit and red blood cells concentrations in these samples were decreased in environmentally samples compared to other groups. Also, spirometric analysis shows significant decreased in forced vital capacity (FVC) and forced expiratory volume in one second (FEV1) for occupationally workers .Peak Expiratory Flow (PEF) and maximum mid Forced Expiratory Flow (FEF25-75) shows significant decreased in both of occupationally and environmentally workers as against the control group. The changes in lung function indicate restriction to the lung expansion and obstruction of the airways in printing presses workers. However, the most examined workers have shown several respiratory symptoms specially allergies in both occupational and environmental samples.
\end{abstract}

\section{Introduction}

The harmful impacts of some emissions, such as fine particulates and air toxics, have only recently been recognized and so have minimal control strategies. Printing of one form or another has been with us for centuries and whilst the technologies of both the printing process and the ink formulations have changed considerably the main functions of decoration and information remain. Offset printing inks are composed of a pigment (one of which is carbon black, which is not much different from the soot used in 2500BC), a binder (an oil, resin or varnish of some kind), a solvent and various additives such as drying and chelating agents. Printing emission is a major source of air pollution in indoor working environment and induce health effects on the workers specially whom are exposed for long time to pollutants. 
Nano particles emitted during printing processes, particulate matter, paper particles, solvents that used with inks more than 10micron size held in upper respiratory tract and particles less than 10-micron size accumulate in the lung and produce respiratory abnormalities. Hence, PM are of great concern in air pollution studies. The effects of air pollution include breathing and respiratory problems, aggravation of existing respiratory and cardiovascular disease, alterations in the body defense systems against foreign materials, damage to lung tissue, carcinogenesis and premature death (Khatri et al.,2013).Sub-mesothelial deposition of carbon nanoparticles in the peritoneum of toner dust exposed worker was reported (Theegarten et al., 2010).

It is clear that Indoor air pollution plays an ever-increasing role in sensitization and allergy.

Irritants do not induce immunochemical responses, and irritation in not sensitized individuals generally leads to slower, less serious respiratory responses and usually requires higher doses of toxicants to produce symptoms than in sensitized people. Irritantinduced inflammation responses (e.g., bronchial hyperactivity) can be severe and prolonged but. Respiratory irritant mixtures can arise from environmental chemical reactions (Baeza-Squiban et al.,1999).

Different form Chronic Obstructive Pulmonary Disease (COPD) and emphysema, which are accompanied by destruction of alveolar walls and are irreversible (Schlegelmilch and Kramme, 2011). Particulates are another source of respiratory irritation when inhaled. Inhaled particulates can adhere to lung surface, adsorb, and bond other vapors that are inhaled, thereby increasing their toxicities. PM2.5 particulates (those with diameters of less than $2.5 \mu \mathrm{m}$ ) that reach the lower respiratory tract as far as the alveoli are more toxic than PM10 particulates of the same composition (Arts et al., 2006).

\section{Heavy Metals}

Offset printing inks may be contain several heavy metals such as Arsenic, Barium, Cadmium, Chromium, Copper, Lead,Mercury, Nickel, Selenium, Silver and Zinc (EPA,1994). The risk of heavy metals in nature comes from the fact that these are considered to be toxic materials, in addition to their effect and bioaccumulation. The poisoning process caused by the heavy metals occurs depending on the way of exposure, either by inhaling,skin contact,and ingesting (Gossel et al., 1996). the adverse human health effects associated with exposure to heavy metals, even at low concentrations, are diverse and include, but are not limited to, neurotoxic and carcinogenic actions (ATSDR, 2004., 2007; Jomova and Valko, 2011; Tokar et al., 2011).

The main objectives of this study includes, Studying the influence of heavy metals $(\mathrm{Pb}$, $\mathrm{Zn}, \mathrm{Cu}$ ) on the workers and detecting these heavy metals concentration in their blood samples.

Investigation whether Occupational exposure to emissions from printing presses is associate with decline in lung function or changes in hematological parameters.

\section{Materials and Methods}

\section{The Study Samples}

Seventy six workers were taken from Printing Presses within Baghdad city; the First group consisted of workers with occupational exposure 25 male (they were 
directly involved in the printing processes) (printers staff). The second group included persons with environmental exposure (they were not directly concerned with printing processes)(counting, sort, bookbinding and censorship workers) 26 male and female employs were selected far away from printing machines. The third group represented the control sample,which consisted of 25 healthy people of both sexes male and female living far away from printing presses. The study was carried out between January 2015 and June 2015 to determine the concentrations of heavy metal levels $(\mathrm{Pb}, \mathrm{Zn}, \mathrm{Cu})$ in the workers blood and its effects on workers blood parameters, as well as, pulmonary function test, respiratory symptoms that workers suffering who exposed to chemical materials and solvents used in printing process.

\section{Samples}

All experimental samples were randomly collected and subjected to personal survey using well prepared questionnaire consisting various items such as ages, gender, working date, exposure time, and health history in addition to the most common health disorders that the workers suffering from, and other physical health symptoms. The samples included both smokers and nonsmokers. These groups have had different working years (exposure period), different blood groups,different smoking habits. So these factors may affect concentration of metals.

\section{Measuring the Concentrations of Heavy Elements in Blood}

Blood sample was collected (6-8) $\mathrm{ml}$ from the venous blood of the workers of both groups and control groups in early morning 9:00 a.m.by sterile plastic disposable injections.blood lead content was measured by an atomic flame spectral absorption (flame atomic absorption ) (Haswell,1991). The flame atomic absorption is the best and the simplest one used to measure the concentrations of the heavy elements and other elements in the sample. While serum of each of Zinc and Copper were measured by flameless atomic absorption. Blood group was determined for each sample by $A B O$ set. The total number of white blood cells, hemoglobin, packed cell volume and red blood cells were measured by using ruby system.

\section{Pulmonary Function Test (PFT)}

It is a primary evaluation of the pulmonary function by measuring lung capacities. The primary purpose of pulmonary function testing is to identify the severity of pulmonary impairment. Pulmonary function was assessed by using spirolab III (MIR), Italy. Spirometry was performed according to the American Thoracic Society guidelines (Miller et al.,2005).

Parameters used for analysis of the flowvolume curve were:

Forced Vital Capacity (FVC).

Forced Expiratory Volume in 1 second (FEV1).

Ratio (FEV1/FVC).

Peak Expiratory Flow (PEF).

maximum mid Forced Expiratory Flow (FEF25-75).

Results were expressed as percentages of predicted values, using equations published in 1993 by the European Respiratory Society. Spirometers are noninvasive diagnostic instruments for screening and basic testing of pulmonary function. 
Offering essential diagnostic insight into the type and extent of lung function impairment, spirometry tests can be performed fast at low cost. In the light of an ever-increasing prevalence of airway diseases such as asthma, bronchitis, and emphysema, pulmonary function instruments have become indispensable diagnostic tools, in clinical and office settings, in industrial and preventive medicine, as well as in epidemiology.

\section{Statistical Analysis}

The Statistical Analysis System- SAS (2012) ANOVA was used to showed the effect of different group in study parameters. Least significant difference-LSD test was used to significant compare between means in this study.

\section{Results and Discussion}

\section{Heavy Metals in Blood Samples}

This work has shown elevated blood lead content in occupational workers tested. Mean lead blood content of examined samples were shown significant differences for those two samples at $(\mathrm{P} \leq 0.01)$ as a compared with environmental and control samples, where the highest value $(26.96 \pm 1.59 \mu \mathrm{gPb} / \mathrm{dl})$ was found in occupational blood samples, while the least value $(17.84 \pm 0.37 \mu \mathrm{gPb} / \mathrm{dl})$ was recorded for control blood sample. Environmental exposed workers have shown a mean of (22.54 $\pm 1.65 \mu \mathrm{gPb} / \mathrm{dl})$ fig. (1)

This study found the blood lead level is higher in occupational and environmental workers respectively than other countries such as USA $(10 \mu \mathrm{gPb} / \mathrm{dl})$ and Germany (15 $\mu \mathrm{gPb} / \mathrm{dl}$ ). Similar work (Bushra,2007; Muna and Hala,2009) has assessed blood lead content in occupational workers of printing presses in Baghdad city and reported almost similar findings. She however explained elevated lead concentrations being due to released lead from printing process.

Blood zinc content also showed elevated zinc concentrations in occupational workers tested $(93.44 \pm 1.90 \mu \mathrm{g} \mathrm{Zn} / \mathrm{dl})$ in comparison with control group $(86.16 \pm 1.08 \mu \mathrm{g} \mathrm{Zn/dl})$ fig.(2) Environmental exposed workers have shown a mean of $(89.92 \pm 1.96 \mu \mathrm{g} \mathrm{Zn/dl})$. However,the Differences between mean Zinc blood content of both occupational workers and control were found significant $(\mathrm{P} \leq 0.05)$, but all differences between these means of occupational and environmental exposed samples were insignificant $(\mathrm{P}>0.05)$.No differences were recorded between environmental and control samples. The differences of zinc concentrations in occupational exposure samples might be attributed to the differences in the methods of chemical analysis, sample size, the type of industry and the exposure period ( ISO, 1998 ).

As well as, It was noticed that a relation between the concentration of zinc and copper,So any increase in the ratio of zinc in human body may lead to decrease in the copper concentration and vice versa.This may be due to the enzymatic relation between copper and zinc (Elinder, 1986). (Mc kenzie,1989) assured that there is a physiological relation between copper and zinc in workers in a copper factory.

In contrast, blood copper content found the highest value in environmental samples tested $(136.62 \pm 1.75 \mu \mathrm{gCu} / \mathrm{dl})$ followed by those of both $(134.64 \pm 1.40 \mu \mathrm{gCu} / \mathrm{dl}$ and $118.60 \pm 2.59 \mu \mathrm{gCu} / \mathrm{dl}) \quad$ occupational and control samples respectively. The differences between mean Copper blood content of both environmental workers and control were found significant $(\mathrm{P} \leq 0.01)$, but all 
differences between these means of occupational and environmental exposed samples were insignificant $(\mathrm{P}>0.01)$. Significant differences $(\mathrm{P} \leq 0.01)$ were recorded between occupational and control samples.fig.(3)

As it has been much known, blood heavy metals concentrations may be affected by several factors such as type and level of exposure, work nature, the way inks and solvents used, emitted deposits behavior, and other characters related to the workers such as age, sex, exposure period, and health condition (IPCS, 1998,1999,2006) and because of non-conformity between copper levels and the exposure period in all samples of the study may be attributed to a number of environmental factors represented by the nature and kind of food,for example, as the rates of copper concentrations vary according to the kinds of food because food contains different level of copper e.g. in meat, sea food, nut, grains as well as in the liver and the brain ( IOM,2001). These levels of copper concentrations partially adding a daily rate of copper to the body.Some drugs help to increase the rates of copper.Blood transfusion among donors which does not take into consideration many environmental factors

An cumulated exposure showed significant differences $(\mathrm{P} \leq 0.05)$ with mean heavy metals blood content,where cumulated exposure recorded $(40.25 \pm 1.87) 1000 \mathrm{~s} / \mathrm{h}$ for occupational samples and $(33.85 \pm 1.55) 1000 \mathrm{~s} / \mathrm{h}$ for environmental exposure samples. Accumulated exposure was assessed by the amount of time spent in Printing presses places :

No. of hours exposed $(1000$ s of hours $)=$ No. of working hours/day $\times$ No. of working days/week $\times$ No. of years of exposure $\times 50$ weeks/year.

\section{Heavy Metals and Blood Group}

In case of blood groups, no significant differences between means of all blood groups values were found, the highest value of lead concentration $(24.43 \pm 1.59)$ was found in individuals with (A) blood group then $(24.11 \pm 2.63)$ was found in individuals with $(\mathrm{AB})$ blood group while individuals with (B) blood group was found $(24.00 \pm 1.60)$ while the least value found in (O) blood group $(21.75 \pm 1.57)$ fig.4.Also the highest value of zinc concentration $(92.16 \pm 2.67)$ was found in individuals with (B) blood group then $(90.45 \pm 1.85)$ was found in individuals with $(\mathrm{O})$ blood group while individuals with $(\mathrm{AB})$ blood group was found $(90.33 \pm 3.36)$ while the least value found in (A) blood group $(88.95 \pm 1.73)$. While the highest value of copper concentration (138.69 \pm 1.57$)$ was found in individuals with (A) blood group then $(136.17 \pm 1.91)$ was found in individuals with (B) blood group while individuals with (O) blood group was found $(135.21 \pm 1.61)$ while the least value found in $(\mathrm{AB})$ blood group (134.56 \pm 2.74$)$. This study unable to found significant differences between all of these blood group values and mean of heavy metals.

\section{Heavy Metals and Smoking Habit}

The impact of cigarettes smoking habit on Lead, Zinc and Copper blood content was unclear in case of occupational sample and environmental sample.In case of blood lead content, the values for smoking samples were $(22.60 \pm 0.97 \mu \mathrm{g} / \mathrm{dl})$ in occupational and environmental samples, respectively, while for non-smoking samples the values were $(24.92 \pm 1.66 \mu \mathrm{g} / \mathrm{dl})$ in occupational and environmental samples. The differences between smoking and nonsmoking samples were insignificant $(\mathrm{P}>0.05)$ in case of 
occupational workers and environmental workers respectively.

Regarding blood zinc content, the values for smoking samples were $(90.47 \pm 1.39 \mu \mathrm{g} / \mathrm{dl})$ in occupational and environmental samples, respectively, while for non-smoking samples the values were $(90.23 \pm 1.80 \mu \mathrm{g} / \mathrm{dl})$ in occupational and in occupational and environmental samples. The differences between smoking and nonsmoking samples were insignificant $(\mathrm{P}>0.05)$ in case of occupational workers and environmental workers respectively (Fig 5).

For blood copper content, blood content values in cigarette smokers of both occupational and environmental samples were $(135.98 \pm 1.91) \mu \mathrm{g} / \mathrm{dl}$ while for nonsmoking samples the values were (137.31 \pm 1.41) $\mu \mathrm{g} / \mathrm{dl}$, the differences between smoking and nonsmoking samples were insignificant $\quad(\mathrm{P}>0.05)$ in case of occupational workers and environmental workers respectively.

\section{Hematological Status}

Levels of circulating total white blood cells and Red blood cells showed significant differences among occupational sample and environmental sample when compared to controls. Hemoglobin and hematocrit levels were highly significant among environmental samples when compared to control samples and occupational samples. No differences was noticed in the levels of Hemoglobin and hematocrit between occupational samples and control. Table 1.

This reduction may be because of exposure to nanoparticles that emitted from offset inks content. A study of Another study showed significant reduction of $\mathrm{RBC}, \mathrm{WBC}, \mathrm{Hb}$ and PCV in male mice when injection to lead oxide (AL-Fartosi,2008). Also the study of
(Bushra et al.,2007) was concluded that if the concentration of lead in blood of workers who are exposed to inorganic lead in a printing house is increased to more than the normal value so the concentration of hemoglobin is decreased.This because is accumulation of lead is increased in the body if the duration of exposure is increased even if the concentration of lead is lower than the maximum small permissible level.

Hematocrit is the volume of red blood cells expressed as a percentage of a given volume of whole blood.Smoking status may be effect on hematocrit according to the Body Mass Index(BMI). The highest value of hematocrit recorded $(46.00 \pm 0.94)$ accompanied increase of BMI (22.6) in occupationally exposed samples. While, environmental exposed samples hematocrit recorded (36.28 \pm 0.78$) \quad$ accompanied decrease in body mass index (17.48).

BMI body mass index ; pack years = (Average number of cigarettes per day/20) $\times$ (number of years smoked).

\section{Lung Function}

Regarding lung function test showed significant difference in \% predicted values of forced vital capacity (FVC) at probability $(p<0.05)$ between the workers and control subjects, while forced expiratory volume in 1 second (FEV1), peak expiratory flow (PEF) and maximal mid expiratory volume (FEF25-75) recorded a significant differences at probability $(\mathrm{p}<0.01)$ (Table.2). (FEV1/FVC) found no significant difference was observed between the workers and control subjects.

Forced Vital Capacity (FVC) is the maximal amount of air that can be exhaled following a maximal aspiratory effort. It was observed that the highest value for average FVC was 
found(99.41 \pm 4.75$) \%$ in environmental sample compared to the average FVC of control sample $(94.95 \pm 2.09) \%$ while the least value $(80.07 \pm 5.63) \%$ was recorded for occupational sample.

Forced Expiratory Volume (FEV1) is the volume of air exhaled in a one second during a forced vital capacity effort. The highest value for average FEV1was found (90.57 \pm 4.79$) \%$ in environmental sample compared to the average FEV1 of control sample $(92.47 \pm 2.21) \%$ while the least value $(72.80 \pm 4.89) \%$ was found in occupational sample.

Relative Forced Vital Capacity (FEV1/FVC) is the FEV1 in \% of the FVC. The average of relative forced vital capacity were decreased to $(90.92 \pm 4.52) \%$ and $(91.10$ $\pm 4.07) \%$ in occupational and environmental samples respectively compared with (97.38 $\pm 0.68) \%$ in control sample.

Peak Expiratory Flow PEF is the maximum amount of air exhaled with forced effort during the FVC. The averages both of PEF values were decreased to $(46.55 \pm 2.49) \%$ and $(53.06 \pm 2.95) \%$ in occupational and environmental samples respectively and recorded a significant differences at $(\mathrm{p}<0.01)$ compared with $(81.09 \pm 3.55) \%$ in control sample.

Mean Forced Expiratory Flow (FEF25-75) between $25 \%$ and $75 \%$ of Forced Vital Capacity.The average of FEF25-75 in occupational sample were decreased to (48.79 \pm 2.85$) \%$ compared with control sample $(81.55 \pm 2.92) \%$ and recorded a significant differences at probability $(\mathrm{p}<0.01)$. While The average of FEF25-75 were found $(60.92 \quad \pm 4.98) \%$ in environmental sample. Significant differences were found between occupational and environmental samples at $(\mathrm{p}<0.01)$.
There are reports on emissions from printing equipment indicating the presence of a complex mixture, which includes particulates, ozone and volatile organic compounds VOCs (Lee and Hsu, 2007; Morawska et al., 2009; Tang et al., 2012). This reduction in lung function parameters recorded in occupational and environmental groups exclusively who exposed to the printing emissions compared to control groups due to the inhaled pollutants work environment,lack of good ventilation, poor indoor air quality in addition to disrupted most of air dischargers.

Fine particulates one of the most common air pollutants that effects on human health and make changes in pulmonary function.fine particulates emitted from printing machines during the process of printing and bookbinding and settle deeply in the lungs, due to their small size they are able to reach the alveoli and stability in the gas exchange region.

In addition, the cumulative of occupational exposure workers greater than cumulative exposure in environmental workers this explains the decline of lung function parameters in occupational workers compared to environmental workers as well as the different of work nature and the smoking status between the two groups .

\section{Lung Function and Smoking Status}

The impact of cigarettes smoking status on Lung function parameters show significant reduction between smoker and nonsmoker groups in forced expiratory volume in 1 second (FEV1) and peak expiratory flow $(\mathrm{PEF})$ at $) \mathrm{P}<0$. (05 fig.6.while, forced vital capacity (FVC), FEV1/FVC and maximal mid expiratory volume (FEF25-75) did not show any significant differences between smoker and nonsmoker groups. 
The current study revealed that there were no differences observed in the average of FVC $(94.26 \pm 4.54) \%$ in smoker workers compared with $(100.00 \quad \pm 3.67) \%$ in nonsmoker workers while the average of FEV1 recorded significant reduction at ) $\mathrm{P}<0$. (05in smoker workers $(83.08 \pm 3.79) \%$ compared to $(92.17 \pm 3.43) \%$ in nonsmoker workers, No clear differences in the averages both of FEV1/FVC $(89.43 \pm 2.79) \%$ and FEF25-75 $(65.60 \pm 4.33) \%$ in smoker workers in compared with FEV1/FVC $(93.15 \pm 1.99) \%$ and FEF25-75 $(70.41 \pm 3.74) \%$ in nonsmoker workers, While the average of PEF showed significant reduction at $) \mathrm{P}<0$. (05in smoker workers $(48.61 \pm 2.50) \%$ compared to $(56.67 \pm 2.95) \%$ in nonsmoker workers. This significant differences might be due to the high pack years smoked between the cohorts.

\section{Respiratory Diseases}

Prevalence of respiratory diseases (restriction and/or obstruction) is presented in Table 4. High prevalence of obstructive lung disease $(32 \%$ among occupational group and $27 \%$ among environmental group) was observed compared to restrictive lung disease $(20 \%$ among occupational group and $11.5 \%$ among environmental group).

Table 5. describes the severity of pulmonary function impairment, respiratory diseases (mild, moderate and severe) regardless the type of impairment, it shows that occupational group had eleven members with mild impairment, two members with moderate impairment, with absence of sever impairment, While environmental group had five members for each mild and moderate impairments respectively with absence of sever impairment. The changes in lung function indicate restriction to the lung expansion, obstruction and narrowing of the airways in printing press workers.

\section{Health Adverse Effects}

The most found syndromes among workers of both working sites were inhaling,skeletal, dermal, urinary, digestive and others related to cardiovascular fig 7.In case of occupational group, the highest value (19) status related to both of respiratory system and skeletal system respectively. However, similar higher percentage (18) status has been found in case of environmental group but to be related to the skeletal system and (13)status for respiratory system. The health troubles were found (7) status for urinary problems and (4) status of digestive problems in environmental workers compared with (4)status and (2) status in occupational workers. However, cardiovascular problems in both study samples had similar values one status for occupational and environmental workers respectively).

Indoor air pollution causes many of health problems for human such as acute and chronic respiratory problems and lung cancer.Most of diseases that found in all the study's samples like the respiratory, dermatitis,circulatory, urinary,skeletal,and digestive diseases were recorded in many researches (Elinder,1986;Quentin, 2001; KOK et al.,2002). These health influences were statistically correlated to the exposure periods and not to the worker ages. These findings however are in agreement with the results those available studies (IPCS, 1988, 1999, 2001a).

The highest value was found to be related to respiratory system and the skeletally system,whilst the remaining diseases (dermal,urinary, digestion and others) had almost similar percentages. 
Table.1 Hematological Parameters in all Examined Samples according to Worked Nature

\begin{tabular}{|c|c|c|c|c|}
\hline \multicolumn{5}{|c|}{ Mean \pm standard error } \\
\hline $\begin{array}{c}\text { RBC } \\
\left(10^{6} / \mu \mathrm{l}\right)\end{array}$ & $\begin{array}{c}\text { Hematocrit } \\
(\%)\end{array}$ & $\begin{array}{l}\text { Hemoglobin } \\
\text { (g/dl) }\end{array}$ & $\begin{array}{c}\text { Total } \\
\text { WBC } \\
\left(\mathbf{1 0}^{3} / \mu \mathrm{l}\right)\end{array}$ & $\begin{array}{l}\text { Kind of } \\
\text { Sample }\end{array}$ \\
\hline $\begin{array}{c}0.11 \pm 5.1 \\
4\end{array}$ & $46.000 .94 \pm$ & $15.000 .28 \pm$ & $\begin{array}{c}0.45 \pm 8.8 \\
2\end{array}$ & $\begin{array}{l}\text { Occupational } \\
\text { Sample }\end{array}$ \\
\hline $\begin{array}{c}0.09 \pm 4.4 \\
7\end{array}$ & $36.280 .78 \pm$ & $0.31 \pm 11.76$ & $\begin{array}{c}0.40 \pm 8.2 \\
9\end{array}$ & $\begin{array}{c}\text { Environmenta } \\
\text { I Sample }\end{array}$ \\
\hline $5.20 .17 \pm$ & $46.780 .30 \pm$ & $15.260 .27 \pm$ & $\begin{array}{c}9.12 \pm 0.5 \\
2\end{array}$ & $\begin{array}{l}\text { Control } \\
\text { Sample }\end{array}$ \\
\hline $0.307 *$ & $2.861 * *$ & $1.247 * *$ & $0.659 *$ & LSD value \\
\hline
\end{tabular}

Table.2 Mean of PFT in all Examined Samples according to Worked Nature

\begin{tabular}{|c|c|c|c|c|c|}
\hline \multicolumn{6}{|c|}{ Mean \pm standard error } \\
\hline $\begin{array}{c}\text { FEF25-75 } \\
\%\end{array}$ & $\begin{array}{c}\text { PEF } \\
\%\end{array}$ & $\begin{array}{l}\text { FEV1/ } \\
\text { FVC\% }\end{array}$ & $\begin{array}{c}\text { FEV1 } \\
\%\end{array}$ & $\underset{\%}{\text { FVC }}$ & Kind of sample \\
\hline $48.79 \pm 2.85$ & $46.55 \pm 2.49$ & $90.92 \pm 4.52$ & $72.80 \pm 4.89$ & $80.07 \pm 5.63$ & $\begin{array}{c}\text { Occupational } \\
\text { Sample } \\
\end{array}$ \\
\hline $60.92 \pm 4.98$ & $53.06 \pm 2.95$ & $91.10 \pm 4.07$ & $90.57 \pm 4.79$ & $99.41 \pm 4.75$ & $\begin{array}{c}\text { Environmental } \\
\text { Sample }\end{array}$ \\
\hline $81.55 \pm 2.92$ & $81.09 \pm 3.55$ & $97.38 \pm 0.68$ & $92.47 \pm 2.21$ & $94.95 \pm 2.09$ & Control Sample \\
\hline $10.941 * *$ & $8.673 * *$ & $9.217 \mathrm{NS}$ & $9.207 * *$ & $10.473 *$ & LSD value \\
\hline \multicolumn{6}{|c|}{$\mathbf{P}<0 * *(01)(\mathbf{P}<0.05) *, \mathbf{N S}:$ Non Significant } \\
\hline
\end{tabular}

Table.4 List of PFT Descriptive Results of the Study Population

\begin{tabular}{|c|c|c|c|c|}
\hline \multirow{2}{*}{ Results } & \multicolumn{2}{|c|}{ Occupational group } & \multicolumn{2}{c|}{ environmental group } \\
\cline { 2 - 5 } & Frequency & Percent & Frequency & Percent \\
\hline Normal & 12 & 48.0 & 16 & 61.5 \\
\hline Obstructive & 8 & 32.0 & 7 & 27.8 \\
\hline Restrictive & 5 & 20.0 & 3 & 11.5 \\
\hline Mixed & 0 & 00.0 & 0 & 00.0 \\
\hline Total & 25 & 100.0 & 26 & 100.0 \\
\hline
\end{tabular}


Table.5 List of PFT Descriptive Results according to Severity

\begin{tabular}{|c|c|c|c|}
\hline $\begin{array}{c}\text { Results } \\
\text { Degree of } \\
\text { Severity }\end{array}$ & $\begin{array}{c}\text { Count of } \\
\text { Occupationa } \\
\text { I group }\end{array}$ & $\begin{array}{c}\text { Count of } \\
\text { Environmental } \\
\text { group }\end{array}$ & $\begin{array}{c}\text { Tota } \\
\mathbf{l}\end{array}$ \\
\hline Mild & 11 & 5 & 16 \\
\hline Moderate & 2 & 5 & 7 \\
\hline Sever & 0 & 0 & 0 \\
\hline
\end{tabular}

Figure.1 Mean Blood Lead Content $(\mu \mathrm{g} / \mathrm{dl})$ in all Examined Samples

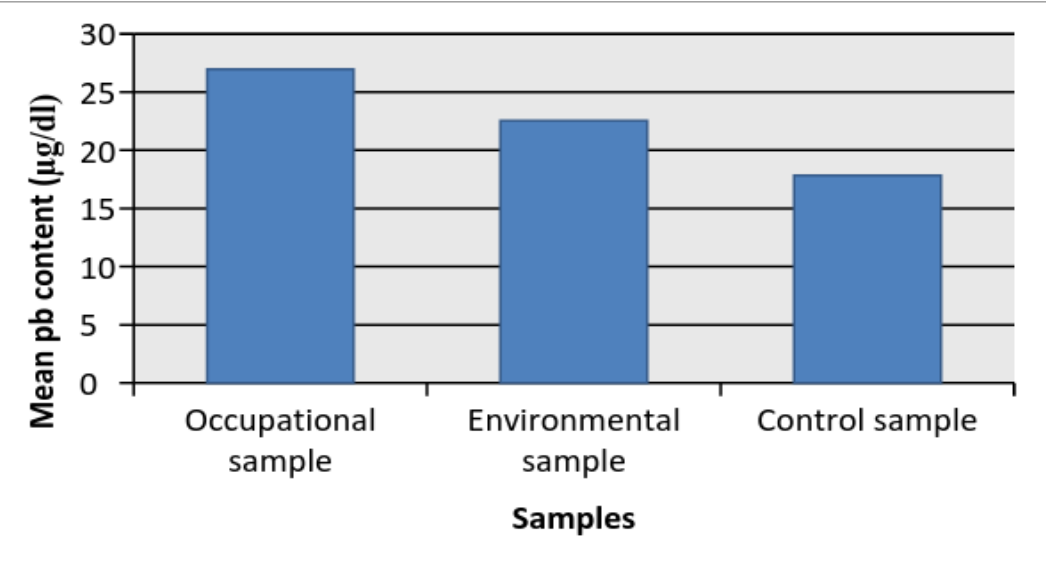

Figure.2 Mean Blood Zinc Content $(\mu \mathrm{g} / \mathrm{dl})$ in all Examined Samples

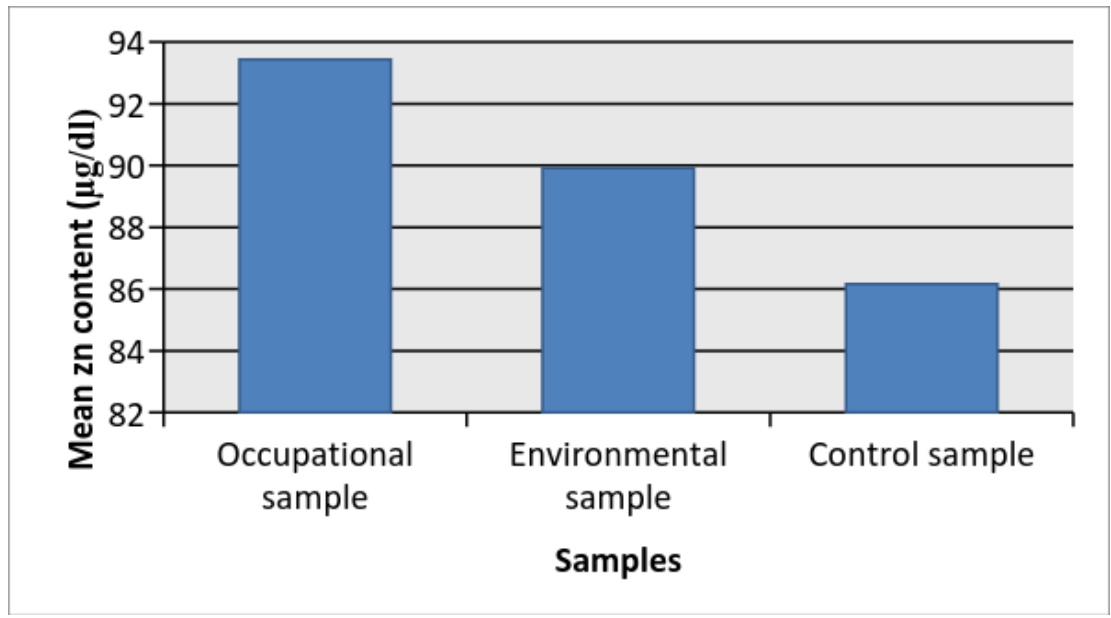


Figure.3 Mean Blood Copper Content $(\mu \mathrm{g} / \mathrm{dl})$ in all Examined Samples

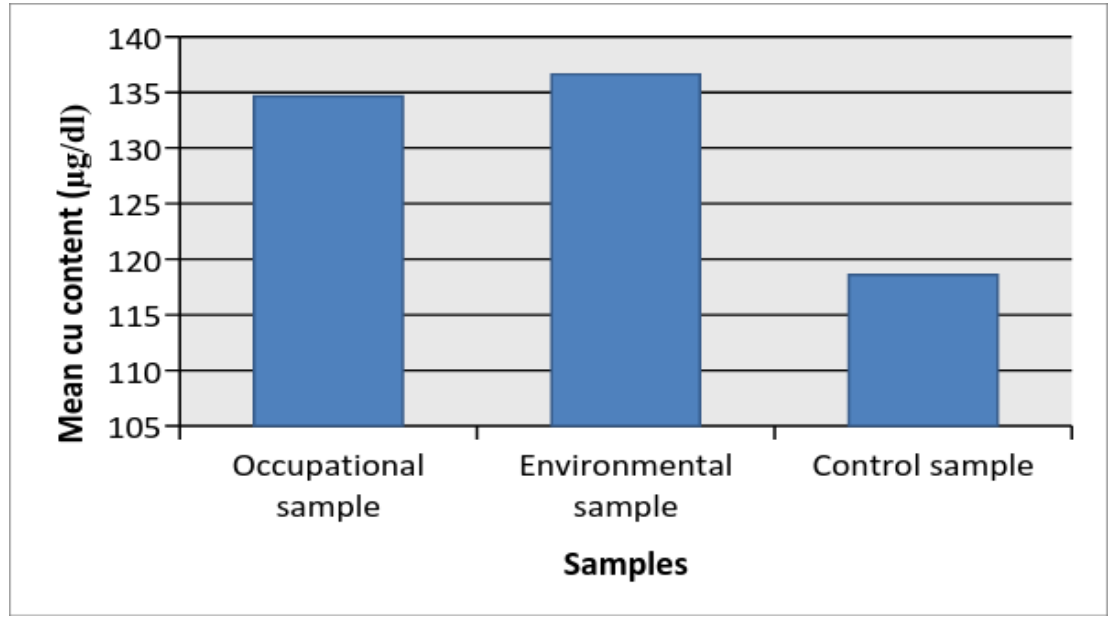

Figure.4 Mean Heavy Metals Concentrations ( $\mu \mathrm{g} / \mathrm{dl})$ in Examined Samples according to Blood Groups

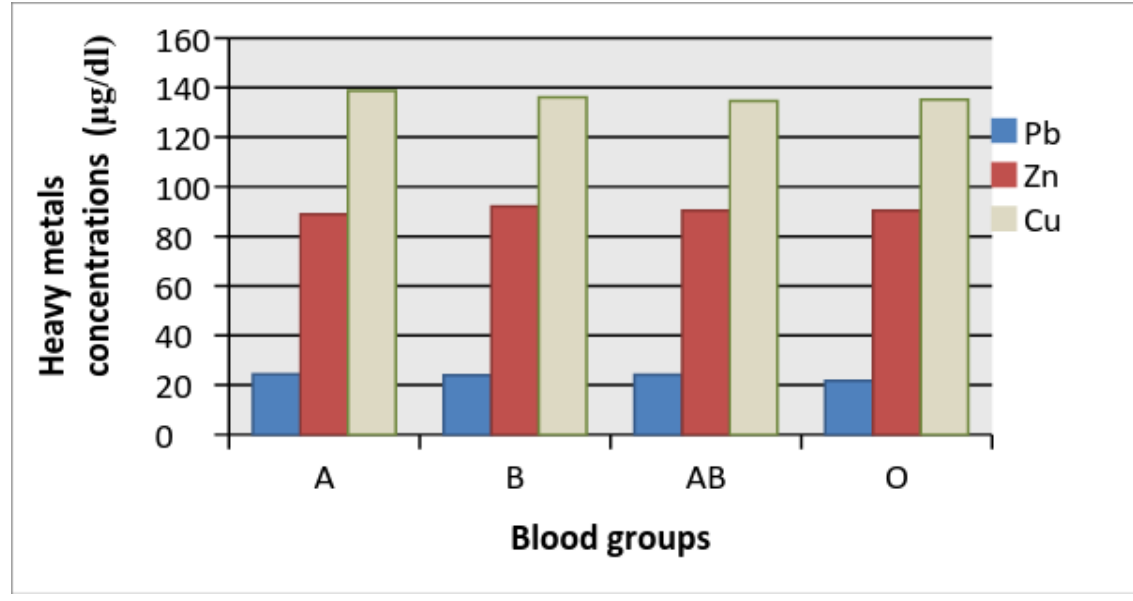

Figure.5 Mean of Heavy Metals $(\mu \mathrm{g} / \mathrm{dl})$ in Study Samples according to Cigarettes Smoking Habit

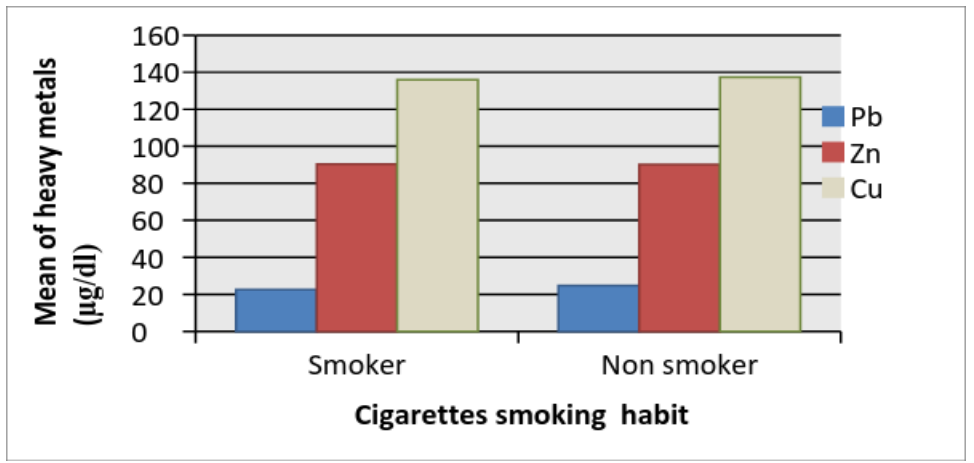


Figure.6 Average of PFT Parameters (\%) in Study Samples according to Cigarettes Smoking Status

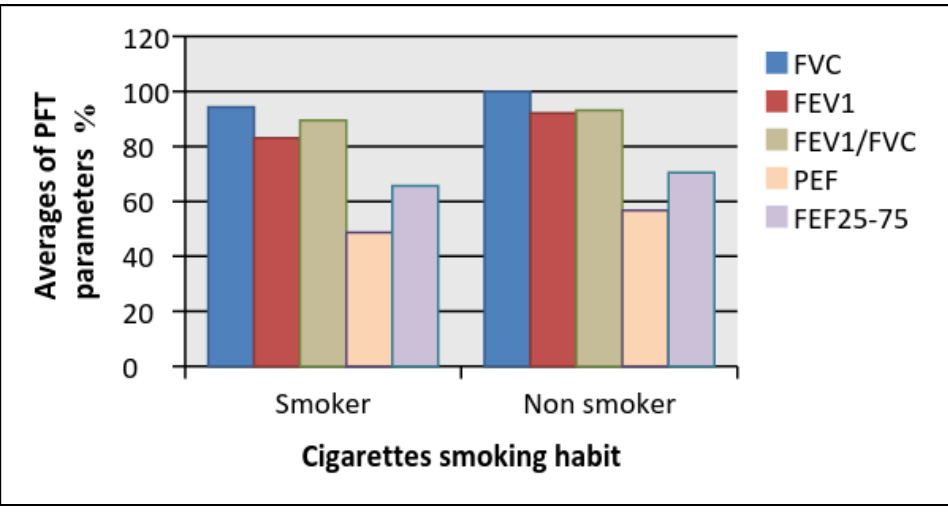

Figure.7 Number of Occupational and Environmental Workers Suffering from Various Diseases

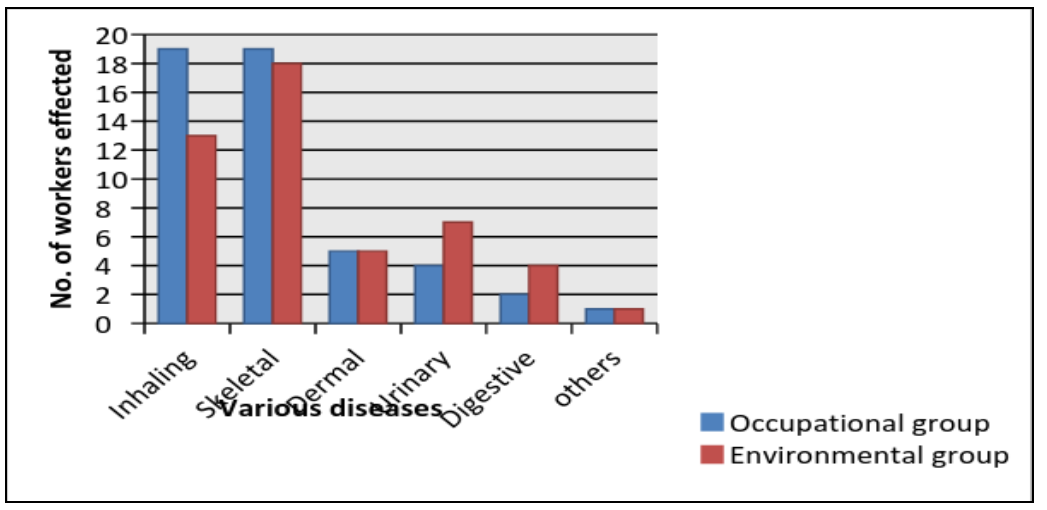

Figure.8 Symptoms of Exposure Found in both Occupational and Environmental Workers

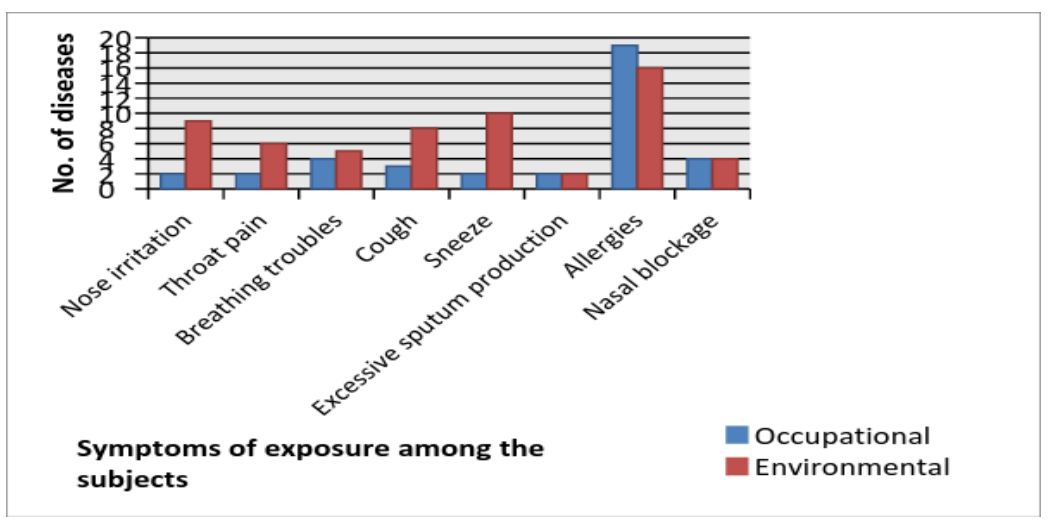


Skeletal problems may be due to effect of accumulated lead in workers bodies because lead element has the ability to assemble in the body, particularly the bones (Fischbein and Sassa.,1975).The toxic effects of lead depend on its quality and quantity in the air and the method of entry into the body. Intestines has a low absorption of lead and most amount of lead taken by mouth out with feces therefor respiratory system considered the main source of lead poisoning .

It is well known that the adverse health effects depend upon the pollutant species, concentration, and behavior (IPCS,2000,2001b,2006). Different PAH, VOC, and various inorganic oxides, where most inhaled concentrations will be held inside human body and only limited quantities are expelled. In general, any contaminant that enters human body via inhaling process or intravenous injection will be transmitted through blood stream to preferable tissues or organs and would start imposing its influences once effective levels being accumulated.

Printing press workers have a high prevalence of respiratory problems specially allergies followed by symptoms nasal blockage, breathing troubles,excessive sputum production, nose irritation, throat pain, cough, sneeze, fig 8 . This might be due to the high particulate matter exposure. Particulate matter might contribute to increased respiratory symptoms and chronic nasal and paranasal sinus problems (Riechelmann et al., 2003; Swiston et al., 2008).

\section{Acknowledgment}

We are thankful to National center for Health and Occupational Safety, Medical City-Ghazi Al-Hareeri Hospital for special syrgical, Toxicants National Center for lab facilities and testing blood samples, Also we are grateful to the Dar Al-Nahrain for printing and publishing, and workers who participated in this study.

\section{References}

Agency for Toxic Substance and Disease Registry (ATSDR). 2007. Toxicological Profile for Lead U.S. Department of Health and Humans Services, Public Health Humans Services, Centers for Diseases Control. Atlanta.

Agency for Toxic Substances and Disease Registry $\quad 2004$. Toxicological Profile for Copper. U.S. Department of Health and Humans Services, Public Health Service, Centers for Diseases Control. Atlanta.

AL-Fartosi,K.G. 2008.Effect of selenium and lead on some blood parameters of male mice. J. Dohouk Univ., 11 (1):p 62.

Arts, J.H., Mommers, C., de Heer, C. 2006. Dose-Response relationships and threshold levels in skin and respiratory allergy. Crit Rev Toxicol., Vol.36 No.(219 - 51). P:3.

Baeza-Squiban, A., Bonvallot, V., Boland, S., Marano, F. 1999. Airborne particles evoke an inflammatory response in human air epithelium. Activation of transcription factors. Cell BiolToxicol., 15:375 - 80.

Bushra, k.Hassan., Farah, K. Naoum., Shatha, Abdulrazaq. 2007 The Effect of Inorganic Lead on The Proportion of Coproporhyrin in the Urine of Workers Who are Exposed to Lead in A Printing House. Al-Taqani journal., 20 (1).

Elinder, C.G. 1986.Zinc. In: Friberg, L., Nordberg, G.F., Vouk, V.B. Handbook on the toxicology of 
metals. 2nd ed. Amst. Elsev. Sci. publ : 664-679.

Environmental Protection Agency (EPA). 1994.Innovative Clean Technologies Case Study. $2^{\text {nd }}$ year Project Report. Reducing Heavy Metals Content in Offset Printing Inks.by Telschow, R. p 117-125.USA.

Fischbein, A. Sassa,S.1975.Blood lead and proto-porphyrin level in lead exposed workers the application of new method for the detection of lead poisoning. In proceedings of the international conference on heavy metals in the environment.Toronto, Canada,October.p 27-31.

Gossel, I. A., Ivaucheva, J., Asenova, L.1996.An emission, In report and proceeding of the work shop on the assessment of EMEP activities concerning heavy metals and persistent organic pollution and their further development. Vol. 117: 125128.

Hasswell， S.J. 1991.Atomic Absorption spectrometry.Theory, Design and Application. 5th edition Edited by the university of Hull, Elseier.p:420-422 .

International Programs of Chemical Safety(IPCS).1988. Vanadium Environmental Health Criteria, EHC81, WHO.

International Programs of Chemical Safety (IPCS). 1999. Principals for the Assessment Risks to Human Health from Exposure to Chemicals. Environmental Health Criteria, EHC210, WHO.

International Programs of Chemical Safety (IPCS).2000. Human Exposure Assessment. Environmental Health Criteria, EHC214, WHO.

International Programs of Chemical Safety (IPCS).2001a. Principals for Evaluating Health Risks Associated with Exposure to Chemicals.
Environmental Health Criteria,
EHC225, WHO. International Programs of Chemical Safety (IPCS).2001b. Principals and Methods for the Assessment of Risk from Essential Trace Elements. Environmental Health Criteria, EHC228. WHO.

International Programs of Chemical Safety(IPCS). 2006. Principals and Methods for the Assessing Autoimmunity Associated with Chemicals. Environmental Health Criteria, EHC236, WHO.

IOM. 2001. Dietary reference intakes for vitamins, arsenic, boron, chromium, copper, Iodine, iron, manganese, molybdenum, Nickel, Silicon, vanadium and zinc. A report of the parcel on micronutrient, sub committees on upper reference level of nutrient and of the International and use of dietary reference intake, and the standing committee on the scientific evaluation of dietary reference intakes. Food and notation board. Instituted medicine. Washington. DC, National Academy press.

International Organization for standardization(ISO). 1998. Water quality-determination of cobalt, nickel, zinc, copper, cadmium and lead by flam atomic absorption spectrometric methods. Geneva. 822: 632-652.

Jomova, K., Valko, M. 2011. Advances in metal-induced oxidative stress and human disease. Toxicology., 283: 6587.

Khatri, M., Bello, D., Gaines, P., Martin, J., Pal, A.K., Gore, R., Woskie, S. 2013. Nanoparticles from photocopiers induce oxidative stress and upper respiratory tract inflammation in healthy volunteers. Nanotoxicology. $7(5)$. 
Kok, F. J. 2002.Serum copper and zinc and the risk of death from cancer and cardiovascular diseases. Am. $J$ of Epidemiol., 143: 204-212.

Lee, C. Hsu, D. 2007. Measurements of fine and ultrafine particles formation in photocopy centers in taiwan. Atmos Environ 41: 6598-609.

McKenzie, J. M. 1989.Content of zinc and copper in serum, urine,hair and toenails of New Zealand workers.Am.J. of Clinic. Nutr. Vol 32:570-579.

Miller, M.R., Crapo, R., Hankinson, J., Brusasco, V., Burgos, F., Casaburi, R., Coates, A., Enright, P., van der Grinten, C.P.M., Gustafsson, P., Jensen, R., Johnson, D.C., MacIntyre, N., McKay, R., Navajas, D., Pedersen, O.F., Pellegrino, R., Viegi, G., Wanger, J.2005. General considerations for lung function testing. Series ATS/ ERS Task Force: standardisation of lung function testing, Edited by Brusasco, Crapo, R., Viegi, G. Eur Respir J., 26:153-161.

Morawska, L. He, C. Johnson, G. 2009. An investigation into the characteristics and formation mechanisms of particles originating from the operation of laser printers. Environ Sci Technol 43:1015-22.

Muna, H. Jankeer., Hala, A. Al-Safar. 2009. Study of some biochemical variables in serum of workers blood upon occupationally exposed to lead pollution.J. Education and Science. 22 (1). p :21-22.
Quentin, K. E. 2001. Occurrence and determination of heavy metals compound in men. Zentralbl. $J$. of Med. 172,514-523.

Riechelmann, H. Rettinger, G. Weschta, M. Keck, T. Deutschle, T. 2003. Effects of low toxicity particulate matter on human nasal function. $J$ Occup Environ Med, 45:54-60.

Schlegelmilch, R.M., Kramme, R. 2011. Pulmonary Function Testing.Springer Handbook of Medical Technology.p:95-104.

Statistical Analysis System (SAS). 2012. User's Guide.Statistical. Version 9. $1^{\text {th }}$ ed.SAS. Inst. Inc. Cary. N.C. USA.

Swiston, J.R. Davidson, W. Attridge, S. Li, G.T. Brauer, M. van Eeden, S.F. 2008. Wood

smoke exposure induces a pulmonary and systemic inflammatory response in firefighters. Eur Respir J, 32:129-138.

Tang, T. Hurrab, J. Gminski, R. MerschSundermann, V. 2012. Fine and ultrafine particles emitted from laser printers as indoor air contaminants in German offices. Environ Sci Pollut Res Int 19(9):3840- 3849.

Theegarten, D., Boukercha, S., Philppou, S., Anhenn, O. 2010. Submesothelial deposition of carbon nanoparticles after toner exposition: case report. Diagn Pathol., 5(77).

Tokar, E.J., Benbrahim-Tallaa, L., Waalkes, M.P. 2011. Metal ions in human cancer development. Metal Ions on Life Science., 8:375-401.

\section{How to cite this article:}

Zainab N. Abdulateef and Adel H. Talib. 2016. Impacts of Printing Presses Emissions upon Occupationally Exposed Workers Health. Int.J.Curr.Microbiol.App.Sci. 5(4): 757-771. doi: http://dx.doi.org/10.20546/ijcmas.2016.504.087 